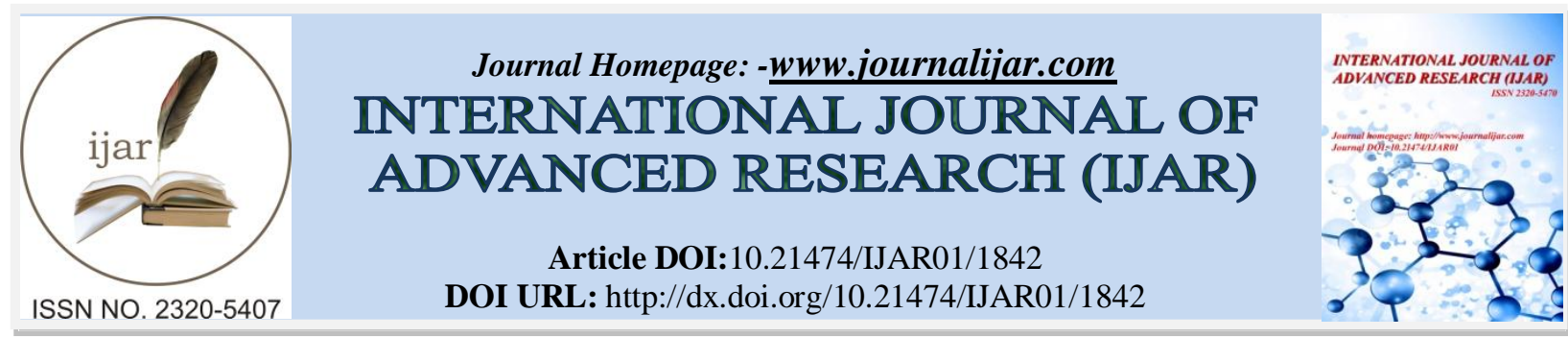

RESEARCH ARTICLE

\title{
ASSESSMENT OF BODY COMPOSITION AND DIETARY INTAKE FOR PRIMARY SCHOOL BOYS IN MAKKAHAREA.
}

Eslam A. Header ${ }^{1,2}$, Hassan M. Bukhari ${ }^{1}$, Nehal A. A. Alfky ${ }^{1}$, Mousa A. Abo Doraib ${ }^{3}$ and Doaa R. Negm ${ }^{1}$.

1. Clinical Nutrition department, Faculty of Applied Medical Sciences, Umm al Qura University, Makkah, Saudi Arabia.

2. Department of Nutrition and Food Science, Faculty of Home Economics, Minufiya University, Egypt.

3. Clinical NutritionDepartment, Hera'a General Hospital,Makkah, Saudi Arabia.

\section{Manuscript Info}

(.........................

Manuscript History

Received: 12 August 2016

Final Accepted: 22 September 2016

Published: October 2016

Key words:-

boys, underweight, obesity, stunting,

body stat, calories.

\section{Abstract}

Background:- Nutritional adequacy might pose a problem on normal child growth. The result of unsatisfactory food intake or severe malnutrition could be seen as stunting, wasting, undernourishment and obesity.

Objectives:- The purpose of this research was to assess body composition and dietary intake for primary school boys in Makkah province.

Methods:- The study was a cross-sectional design conducted on 100 convenience sample in primary schools boys aged between $6-12$ years in Makkah region. Dietary assessment was performed using 24$\mathrm{hr}$ recall. Height and weight were measured by anthropometric methods and the outcomes were BMI z-scores. Body composition was evaluated by bioelectrical impedance approach.

Results:-The mean body fat $\%$ for boys in age group $\leq 8$ yearswas significantly higher compared with boys in age group $>8$ years. While, boys in age group $>8$ years had significantly higher lean, dry lean and body fluid compared boys in another group. The occurrence of stunting was $7.5 \%$ and $16.7 \%$ in both age groups $\leq 8$ and $>8$ resp. There was a highly significant positive correlation $(\mathrm{P}<0.01)$ between height and each of age, waist, hip, and lean body weight. Daily intake of calories intake was pronouncedly lower thanadequate intake (AI) for both groups.

Conclusions:- Differences were found in body composition of boys. Obesity and stunting are prevalent and undernutrition, especially severe thinness, was uncommon in this target group. Calories and fiber intake were lower thanAI. Therefore, nutrition education is recommended as one of the long-term approaches for improving nutrition and health status for boys.

Copy Right, IJAR, 2016,. All rights reserved.

\section{Introduction:-}

The definition of school age group corresponds approximately to the period from kindergarten through lower secondary schooling; it begins after the period of high mortality risk in the preschool years and continues through 
most of the adolescent growth spurts and sexual maturation to young adulthood ${ }^{(\mathbf{1})}$. The preschool children designed for a child between infancy and school age, usually one three to five years of age ${ }^{(2)}$. It is well recognized that preschool children are a nutritionally vulnerable segment of population, also very susceptible to morbidity due to infections ${ }^{(3)}$. Nutrition of preschool child is of paramount importance, because the foundation for life time health, strength and intellectual vitality is laid during that period ${ }^{(4)}$.

Nutrition is one of the most important factors influencing the children health. It plays a vital role in prevention and control of various diseases ${ }^{(5)}$. Health and nutrition problems are the result of unsatisfactory food intake or severe and repeated infections, or a combination of both. These conditions are closely linked to inadequate access to food, neglected care for mothers and children, insufficient health services and unhealthy environment. These parameters are reflected in the standard of living of population, and whether its basic needs are met, for example with adequate food and healthcare ${ }^{(6)}$.

Adequate dietary intakes among children are important for their own growth and development. Developing healthy diet and physical activity patterns early in life is essential so that these practices follow into adulthood, which may prevent obesity, type 2diabetes, and other chronic diseases ${ }^{(7)}$.Thus, childhood diet needs to be taken seriously in order to improve a nation's health as well as producing bright and active children ${ }^{(\mathbf{8})}$.

\section{Subjects and methods:- \\ Subjects and study design:-}

A cross-sectional study was conducted during the academic year (1432-1433h). The study included 100 child selected from the total population; all of them were boysbetween the ages of 6 and 12 years from different schools in Makkah Governorate, Saudi Arabia.

Schools were selected to participate, as were pupils from the selected schools. A quota of 20 students was assigned from each school. If the quota was not achieved, oversampling from other schools was sought to be the solutionn. At the commencement, a letter has been given to every school to indicate our objectives for conducting the research. Another letter has been handed to the parents of the children to seek consent for contribution. Subsequent to getting parent's approval the study was conducted by going to every school at separate days. Parents reported their child's age.

\section{Anthropometric measurements:-}

Measurements were taken at school by research assistants. Height was measured to the nearest $0.1 \mathrm{~cm}$ with a portable HarpendenStadiometer (British Indicators Ltd, London). Weight was measured by portable scales (ClassCap $160 \mathrm{~kg}$, grad $1 \mathrm{~kg}$, China) to the nearest $0.1 \mathrm{~kg}$. Boys were measured without shoes and in light clothing. Body mass index (BMI-for-age) was used to define overweight and obesity, height-for-age (H/A) was used for stunting. The BMI-for-age $\mathrm{z}$ scores were calculated using the recent version of the WHO program for anthropometrics measurements(anthro-plus) for children from the age of 0-19 years. BMI was calculated as weight in kilograms divided by height in meters squared and their corresponding BMI z-scores were compared with the International Obesity Task Force (IOTF) reference data ${ }^{(9)}$ and with reference data from the Disease Control and Prevention $(\mathrm{CDC})^{\mathbf{( 1 0 , 1 1 )}}$ Mid-arm circumference (MAC) was measured with a flexible but non-stretchable measuring tape (steel tape) and was recorded to the nearest 0.1 centimeter. It was measured midway between the lateral projection of the

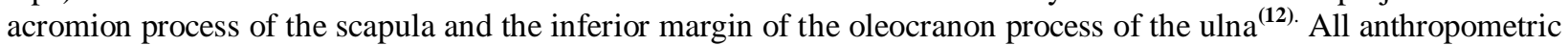
measurements were made on the right hand side of the body whenever possible, and the final value was calculated as the mean of the two closest measurements ${ }^{(13) .}$

\section{Body composition:-}

Body composition using the device of Bodystat ${ }^{\circledR}$ 1500MDD by the technique of BIA for some children were found by entering weight and height in Bodystat ${ }^{\circledR}$ 1500MDD device.

\section{Determination of daily nutrient intake:-}

Daily nutrient intake was obtained for three different days and nutritional values of consumed food were calculated using the computer program software for United States Department of Agriculture USDA ${ }^{(14)}$. The adequacy of diets evaluated with regard to $(\mathrm{AI})^{(\mathbf{1 5 , 1 6}) \text {. }}$ The mean values of food and nutrient intakes of children were calculated separately for each of the two age groups $(\leq 8$, and $>8$ years) The mean values of food and nutrient intakes of children 
were calculated separately for each of the two age groups ( $\leq 8$, and $>8$ years) according to dietary references intake ${ }^{(17)}$.

\section{Statistical analysis:-}

Statistical analysis was performed using the Statistical Package for Social Science (SPSS) version 20. Frequencies, relative and cumulative percentages, means, standard deviation (SD), and range were computed. Quantitative data are presented as mean \pm SD. Qualitative data were expressed as percentages. For the quantitative variables,compliance with the normal distribution was assessed using the Kolmogorov-Smirnoff test, as appropriate. For comparing the groups, the chi-square test or Fisher's exact test were used for qualitative variables as well as the t-test or Mann-Whitney $U$ test for quantitative variables.P value of less than 0.05 was considered to indicate statistical significance.

\section{Results:-}

\section{Sample Disruption:-}

The study sample comprised 100 boys, ages between from 6 to 12 years old (y-old). The majority of investigated children (60\%) were in age group $>8$ y-old, the mean age was $10.7 \pm 1.18$, range $8-12$ years, age distribution and the mean age of studied sample of school children were shown in table 1and fig. 1 .

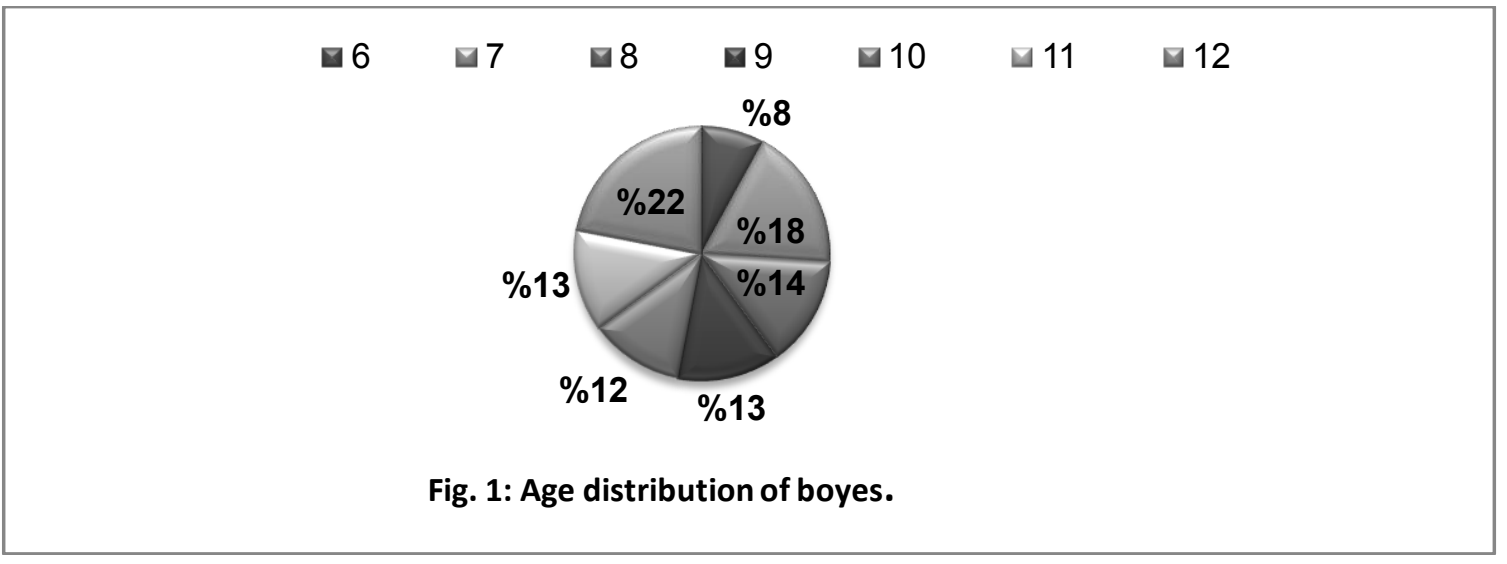

Table 1:-Body composition of investigated boys students.

\begin{tabular}{|l|c|c|c|c|}
\hline \multicolumn{1}{|r|}{ Age groups } & & Age $\leq 8$ (y-old) & Age $>8$ (y-old) & \multirow{2}{*}{$\mathrm{P}^{*}$} \\
\hline Parameters & $R R$ & Mean \pm SD & Mean \pm SD & \\
\hline Fat $(\%)$ & $18-25$ & $30.52 \pm 7.75$ & $26.73 \pm 9.00$ & 0.039 \\
\hline Fat weight (Kg) & $2-13$ & $9.10 \pm 6.49$ & $12.07 \pm 9.86$ & 0.087 \\
\hline Lean (kg) & $13-62$ & $17.62 \pm 3.32$ & $30.15 \pm 28.82$ & 0.000 \\
\hline Dry lean weight (kg) & $3-9$ & $4.07 \pm 0.79$ & $6.46 \pm 1.89$ & 0.000 \\
\hline Water (\%) & $57-66$ & $52.71 \pm 7.16$ & $55.31 \pm 6.11$ & 0.082 \\
\hline Water (ltr.) & $11-53$ & $13.20 \pm 2.30$ & $20.12 \pm 5.60$ & 0.000 \\
\hline
\end{tabular}

$y=$ yearsRR=Recommended Range $S D=$ standard deviation. $\quad P^{*}:$ Mann-Whitney test was done.

\section{Body compositionfor the children:-}

The mean and SD for the body fat as \% of total body weight, body fat in $\mathrm{kg}$, lean muscle mass in $\mathrm{kg}$, and total fluid in the body as \% are shown in table (1). Analyses of all the children revealed that, mean body fat $\%$ for boys in age group $\leq 8$ y-old was significantly higher $(\mathrm{P}=0.039)$ when compared with boys in age group $>8$ y-old $(30.52 \pm 7.75$ vs $26.73 \pm 9$.0resp.). While detailed evaluation of the parameters showed that, mean values of lean and dry lean body $(\mathrm{kg})$ and boy fluid (liter) for boys in age group $>8$ y-old were significantly higher $(\mathrm{p}<0.01)$ compared with boys in another group.

\section{Anthropometric measurements:-}

Descriptive data for body waist, hip and MACfor the studied samples are shown in table (2). The mean values of waist and hip Circumference. for boys in age group $>8$ y-old were significantly higher $(\mathrm{P}<0.001)$ than boys in age 
group $\leq 8 \mathrm{y}$-old, the values were $(68.06 \pm 12.82$ and $81.10 \pm 13.89$ vs $60.97 \pm 6.93$ and $72.67 \pm 6.69 \mathrm{~cm}$ resp. $)$, the same trend was observed for MAC $(24.98 \pm 5.0$ vs $22.10 \pm 3.37 \mathrm{~cm}$ resp. $)$ and it is significant at $\mathrm{P}=0.003$.

Table 2:- Waist, hip and mid-arm circumference of boys.

\begin{tabular}{|l|c|c|c|}
\hline & Age groups & Age $\leq 8$ (y-old) & Age $>8$ (y-old) \\
\hline Parameters & Mean \pm SD & Mean \pm SD & \\
\hline Waist Cir. $(\mathrm{cm})$ & $60.97 \pm 6.93$ & $68.06 \pm 12.82$ & 0.000 \\
\hline Hip Cir. $(\mathrm{cm})$ & $72.67 \pm 6.69$ & $81.10 \pm 13.89$ & 0.000 \\
\hline MAC $(\mathrm{cm})$ & $22.10 \pm 3.37$ & $24.98 \pm 5.41$ & 0.003 \\
\hline
\end{tabular}

$y=$ years $S D=$ standard deviation. $\quad P^{*}:$ Mann-Whitney test was done. MAC =Mid-Arm Circumferencekg.: kilo

gram cm.: Centimeter

The sample distribution according to the height for age is shown in table (3). Using the cutoff value of -2 Z-scores of height-for-age, the overall prevalence of stunting was $7.5 \%$ and $16.7 \%$ in both age groups $\leq 8$ and $>8$ y-old resp., with mean height of $111 \pm 2.6$ and $124.4 \pm 4.2 \mathrm{~cm}(\mathrm{p}=0.007)$, while the prevalence of linear growth deficit $(-2$ to -1 SD height of the median of the NCHSIWHO) in the same age group were $25.0 \%$ and $33.3 \%$ in both age groups. Height level increased gradually when height-for-age Z-score level increased, as the detected data shows for both age groups.

Table 3:-Height for age and the mean height distribution of boys students.

\begin{tabular}{|c|c|c|c|c|c|c|c|c|c|}
\hline \multirow[t]{2}{*}{ Ht for age Z-scores } & \multicolumn{2}{|c|}{ Age $\leq 8(y-o l d)$} & \multicolumn{2}{|c|}{ Age $>8$ (y-old $)$} & \multirow[t]{2}{*}{$\mathrm{X}^{2}$} & \multirow[t]{2}{*}{$\mathrm{P}$} & Ht of $\leq 8 y$ & Ht of $>8 y$ & \multirow[t]{2}{*}{$\mathrm{P}^{*}$} \\
\hline & No. & $\%$ & No. & $\%$ & & & Mean \pm SD & Mean \pm SD & \\
\hline$<-2$ SD Stunting & 3 & 7.5 & 10 & 16.7 & \multirow[t]{4}{*}{$3.39^{\mathrm{a}}$} & \multirow[t]{4}{*}{0.18} & $111 \pm 2.6$ & $124.4 \pm 4.2$ & 0.007 \\
\hline-2 to -1 SD height & 10 & 25.0 & 20 & 33.3 & & & $115.3 \pm 4.2$ & $131.1 \pm 6.1$ & 0.000 \\
\hline $\begin{array}{l}>-1 \mathrm{SD} \\
\text { Normalheight }\end{array}$ & 27 & 67.5 & 30 & 50.0 & & & $123.7 \pm 5.8$ & $144.3 \pm 7.3$ & 0.000 \\
\hline Total & 40 & 100.0 & 60 & 100.0 & & & $120.6 \pm 6.9$ & $136.6 \pm 10.3$ & 0.000 \\
\hline
\end{tabular}

$y=$ years $X^{2}:$ Chi-SquareSD = standard deviation. $\quad P^{*}:$ Mann-Whitney test was done.

Table (4) show that the frequency distribution of studied samples according to grades of BMI-for-age Z-score. The majority of students $(50 \%)$ had normal BMI for age at the level (-2 to $1 \mathrm{SD})$, meanwhile mean values of BMI for boys in age group $\leq 8$ y-old were significantly higher $(\mathrm{P}<0.001)$ than boys in age group $>8$ y-old $(16.6 \pm 1.6$ and $15.5 \pm 1.2 \mathrm{Kg} / \mathrm{m}^{2}$ resp.). It is worth to mentioning that, about $20.0 \%$ vs $21.7 \%$ of boys in both age groups were obese, while $25.0 \%$ vs $21.7 \%$ resp. were overweight. Regarding boys in age group $>8$ y-old, results revealed that only $3.3 \%$ was severely thin $(<-3 \mathrm{SD})$. A curve up shows for BMI as levels of BMI-for-age Z-score for both age groups increased.

Table 4:-BMI for age and the mean height distribution of boys students.

\begin{tabular}{|c|c|c|c|c|c|c|c|c|c|}
\hline \multirow[t]{2}{*}{ BMI-for-age Z-score } & \multicolumn{2}{|c|}{ Age $\leq 8$ (y-old $)$} & \multicolumn{2}{|c|}{ Age $>8$ (y-old $)$} & \multirow[t]{2}{*}{$\mathrm{X}^{2}$} & \multirow[t]{2}{*}{$\mathrm{P}$} & \multirow{2}{*}{$\begin{array}{c}\begin{array}{c}\text { BMI of } \\
\leq 8 \mathrm{y}\end{array} \\
\text { Mean } \pm \text { SD }\end{array}$} & \multirow{2}{*}{$\begin{array}{c}\text { BMI of } \\
>8 y \\
\text { Mean } \pm \text { SD }\end{array}$} & \multirow[t]{2}{*}{$\mathrm{P}^{*}$} \\
\hline & No. & $\%$ & No. & $\%$ & & & & & \\
\hline$<-3$ SD Severe thinness & 0 & 0 & 2 & 3.3 & \multirow[t]{6}{*}{$1.65^{\mathrm{a}}$} & \multirow[t]{6}{*}{.800} & 0.0 & $12.6 \pm 0.6$ & - \\
\hline-3 to $<-2$ SD Thinness & 2 & 5.0 & 2 & 3.3 & & & $14.95 \pm 3.3$ & $13.4 \pm 0.4$ & 0.67 \\
\hline-2 to 1 SD Normal & 20 & 50.0 & 30 & 50.0 & & & $15.5 \pm 1.2$ & $16.6 \pm 1.6$ & 0.00 \\
\hline 1to 2 SD Overweight & 10 & 25.0 & 13 & 21.7 & & & $18.3 \pm 0.8$ & $20.8 \pm 1.2$ & 0.01 \\
\hline$>2$ SD Obesity & 8 & 20.0 & 13 & 21.7 & & & $22.3 \pm 2.3$ & $26.5 \pm 4.5$ & 0.00 \\
\hline Total & 40 & 100 & 60 & 100 & & & $17.91 \pm 3.3$ & $19.43 \pm 4.9$ & 0.15 \\
\hline
\end{tabular}

$y=$ years $X^{2}:$ Chi-SquareSD = standard deviation. $\quad P^{*}:$ Mann-Whitney test was done.

Nutrient intake for boyscompared with adequate intake (AI):-

Data of tables (5) shows the means and standard deviations of several nutrients intake for boys compared with the AI. It could be noticed that calories intake was lower than AI, tending to be lower for boys in age group $>8$ (y-old) than boys in age group $\leq 8$ y-old $(62 \%$ vs. $76 \%$ of AI resp.), $(\mathrm{P}=0.588)$. Total protein intake was highly increased for boys in age group $\leq 8$ y-old $(215.3 \%)$ of AI compared with boys in age group $>8$ (y-old) $(108.5 \%)$ of $A I,(P=0.720)$. 
Concerning carbohydrate, fiber and total sugars there were insignificant differences between both groups $(\mathrm{P}=0.464$, $\mathrm{P}=0.208$ and $\mathrm{P}=0.206$ resp.), meanwhile fiber intakefor boys in age group $>8$ (y-old) was severely decreased compared daily requirements, represent (39\%) of AI. It can be notice that the difference in macro-nutrients intake were non-significant $(\mathrm{p}>0.05)$ between school children in both age groups.

Table 5:-Macro-nutrients intake and its percentage of AI for studied samples.

\begin{tabular}{|l|c|c|c|c|c|c|c|}
\hline \multicolumn{1}{|c|}{ Age groups } & \multicolumn{2}{c|}{ Age $\leq 8$ (y-old) } & \multicolumn{2}{c|}{ Age $>8$ (y-old) } & \\
\hline Parameters & Mean \pm SD & AI & \% of AI & Mean \pm SD & AI & $\%$ of AI & $\mathrm{P}^{*}$ \\
\hline Energy (Kcal) & $1062.1 \pm 430.7$ & 1400 & 76 & $1106.8 \pm 453.1$ & 1800 & $62 \%$ & 0.588 \\
\hline Protein(g) & $40.9 \pm 24.7$ & 19 & 215.3 & $36.9 \pm 18.8$ & 34 & 108.5 & 0.720 \\
\hline Total fat(g) & $35.9 \pm 19.1$ & - & - & $40.1 \pm 21.5$ & - & - & 0.309 \\
\hline Carbohydrate $(\mathrm{g})$ & $143.7 \pm 60.9$ & 130 & 110.5 & $149.56 \pm 60.9$ & 130 & 115.1 & 0.464 \\
\hline Fiber(g) & $19.10 \pm 25.16$ & 25 & 76.4 & $12.10 \pm 11.20$ & 31 & 39 & 0.208 \\
\hline Total sugars(g) & $64.47 \pm 41.21$ & - & - & $51.58 \pm 41.72$ & - & - & 0.206 \\
\hline
\end{tabular}

$y=$ years $\quad A I=$ Adequate Intake - Source: $I O M, 2005 S D=$ standard deviation. $\quad P^{*}:$ Mann-Whitney test was

done.

The mean and SD for protein, fat and carbohydrate as source of energy (energy ratios) for boys are shown in table (6). As regard to total calories derived from protein, It was found protein energy ratio (PER) of boys in age group $\leq 8$ (y-old) were not different significantly $(15.84 \pm 8.9 \%$ of total calories) compared with boys in age group $>8$ (y-old) (13.72 \pm 5.8 of total calories) $(\mathrm{p}=0.477)$. With respect to total calories derived from fat, fat energy ratio (FER) it was almost the same (29.55 \pm 6.4 vs $31.46 \pm 8.5$ of calories) for the two groups. Meanwhile, carbohydrate energy ratio (CER) values were quite equal (54.61 \pm 7.7 vs $54.82 \pm 8.9)$ for both groups respectively.

Table 6:-Mean and SD for protein, fat and carbohydrate energy ratios for boys.

\begin{tabular}{|l|c|c|c|c|}
\hline \multirow{2}{*}{$\begin{array}{c}\text { Age groups } \\
\text { Parameters }\end{array}$} & $\begin{array}{c}\text { Recommended Range } \\
\text { for\% of energy }\end{array}$ & Age $\leq 8$ (y-old) & Age $>8$ (y-old) & \multirow{2}{*}{ value } \\
\cline { 2 - 4 } & & Mean \pm SD & Mean \pm SD & \\
\hline PER & $10-30 \%$ & $15.84 \pm 8.9$ & $13.72 \pm 5.8$ & 0.477 \\
\hline FER & $25-35 \%$ & $29.55 \pm 6.4$ & $31.46 \pm 8.5$ & 0.301 \\
\hline CER & $45-65 \%$ & $54.61 \pm 7.7$ & $54.82 \pm 8.9$ & 0.905 \\
\hline
\end{tabular}

$y=$ years $\quad S D=$ standard deviation. $\quad P^{*}:$ Mann-Whitney test was done.

\section{Correlation coefficients between body composition and nutrient intake:-}

Table (7) showed the correlation coefficients between body composition and nutrients intake for boys. There was a highly significant positive correlation $(\mathrm{P}<0.01)$ between height and each of age, waist, hip, MAC, lean body weight,andHt for Age Zscor. Concerning to waist cir., a positive highly significant correlation $(\mathrm{p}<0.01)$ was reported between it and each of age, hip, MAC, body fat\%, lean body weight, Ht for age Zscor and BMI for age Zscor. As for hip cir., a positive highly significant correlation at level (1\%) was reported between it and each of MAC, body fat $\%$, lean body weight,Ht for age Zscor and BMI for age Zscor. It is obvious that, there was a highly significant positive correlation $(\mathrm{P}<0.01)$ between MAC and each of age, body fat\%, lean body weight, $\mathrm{Ht}$ for age Zscor and BMI for age Zscor. With regard to body fat\%, a highly positive significant correlation at level (1\%) was reported between it and each of and BMI for age Zscor, also there was a significant positive correlation $(\mathrm{P}<0.05)$ between it and carbohydrate intake. Lean body weight correlated significantly positive $(\mathrm{p}<0.01)$ with age, however it correlated significant with energy intake at level (5\%).

Concerning to energy intake, A positive significant relationship $(\mathrm{p}<0.01)$ was existed between it and each of fat, carbohydrate, total sugars intakes, also there was a positive significant association at level (5\%) between it and each of protein and BMI for age Zscor. There was a positive significant relationship between protein intake and fat intake $(\mathrm{p}<0.05)$, however it correlated significantly negative with age $(\mathrm{p}<0.05)$. In addition there was a positive significant correlation between fat intake and each of carbohydrate, and total sugars $(\mathrm{p}<0.01)$. There was also a positive significant relationship $(\mathrm{p}<0.01)$ between carbohydrate intake and total sugars intake. 
Table 7:-Correlation coefficients between body composition and nutrients intake for boys.

\begin{tabular}{|c|c|c|c|c|c|c|c|c|c|c|c|c|c|}
\hline & $\underset{\substack{0 \\
\frac{0 Q}{2}}}{\sum_{0}}$ & 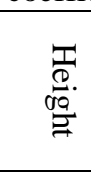 & $\begin{array}{l}\sum_{0} \\
:\end{array}$ & $\Xi$ & 攵 & $\stackrel{\frac{T}{2}}{\stackrel{2}{a}}$ & 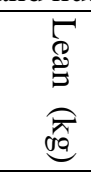 & 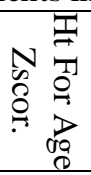 & 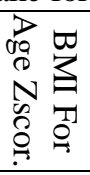 & 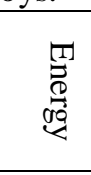 & & $\stackrel{T}{\stackrel{T}{*}}$ & ڤ્. \\
\hline Height & $.757^{*}$ & & & & & & & & & & & & \\
\hline Waist & $.909^{*}$ & $.641^{*}$ & & & & & & & & & & & \\
\hline Hip & $.835^{*}$ & $.608^{*}$ & $.791^{*}$ & & & & & & & & & & \\
\hline MAC & $.799^{*}$ & $.542^{*}$ & $.774^{*}$ & $.751^{*}$ & & & & & & & & & \\
\hline Fat $(\%)$ & $.354^{*}$ & $\begin{array}{c}- \\
.069-\end{array}$ & $.316^{*}$ & $.351^{*}$ & $.393^{*}$ & & & & & & & & \\
\hline Lean $(\mathrm{kg})$ & $.271^{*}$ & $.318^{*}$ & $.258^{*}$ & $.219^{*}$ & .181 & $\begin{array}{c}- \\
.107-\end{array}$ & & & & & & & \\
\hline $\begin{array}{ll}\text { Ht } & \text { For } \\
\text { Age } & \\
\text { Zscor. } & \end{array}$ & $.427^{*}$ & $.515^{*}$ & $.418^{*}$ & $.353^{*}$ & $.304^{*}$ & .084 & .159 & & & & & & \\
\hline $\begin{array}{l}\text { BMI For } \\
\text { Age } \\
\text { Zscor. }\end{array}$ & $.635^{*}$ & .182 & $.647^{*}$ & $.637^{*}$ & $.666^{*}$ & $.603^{*}$ & .107 & $.300^{*}$ & & & & & \\
\hline Energy & .108 & .001 & .121 & .047 & .101 & .168 & $.201^{*}$ & .098 & $.223^{*}$ & & & & \\
\hline Protein & $\begin{array}{c}- \\
.097- \\
\end{array}$ & $\begin{array}{c}- \\
.174- \\
\end{array}$ & $\begin{array}{c}- \\
.074- \\
\end{array}$ & $\begin{array}{c}- \\
.057- \\
\end{array}$ & $\begin{array}{c}- \\
.056- \\
\end{array}$ & .100 & $\begin{array}{c}- \\
.063- \\
\end{array}$ & $\begin{array}{c}- \\
.008- \\
\end{array}$ & .109 & $.210^{*}$ & & & \\
\hline Fat & .080 & .005 & .062 & .034 & .044 & .146 & .111 & .097 & .124 & $.804^{*}$ & $.200^{*}$ & & \\
\hline Carb. & .123 & .020 & .153 & .067 & .163 & $.237^{*}$ & .076 & .095 & $.267^{*}$ & $.632^{*}$ & .113 & $.476^{*}$ & \\
\hline Age & $.590^{*}$ & $.809^{*}$ & $.464^{*}$ & $.473^{*}$ & $.421^{*}$ & $\begin{array}{c}- \\
.145- \\
\end{array}$ & $.272^{*}$ & $\begin{array}{c}- \\
.058- \\
\end{array}$ & .005 & $\begin{array}{c}- \\
.085- \\
\end{array}$ & $.220^{*}$ & $\begin{array}{c}- \\
.091- \\
\end{array}$ & $\begin{array}{c}- \\
.090- \\
\end{array}$ \\
\hline
\end{tabular}

\section{Discussion:-}

Body composition and anthropometric measurements:-

Our results revealed that, stunting was prevalent in both age groups. Height level increased gradually when heightfor-age Z-score level increased, as the detected data show for both age groups. Childhood stunting has been associated with an increased risk of obesity in adulthood, but the causes are unclear ${ }^{(\mathbf{1 8})}$. Stunting affected $35 \%$ of these physically active children. Using multiple linear regression analysis, greater lean body mass predicted higher resting and activity energy expenditure. Stature was not a significant predictor of resting energy expenditure. Alower height-for-age z-score, but not stunting as a categorical variable, significantly predicted lower activity energy expenditure ${ }^{(\mathbf{1 8})}$.

Several studies from developing countries reported similar prevalence data for stunting: $6.2 \%-15.2 \%$ in schools in Brazil in $1990^{(\mathbf{1 9}),} 15.8 \%$ in Nigeria in $2000^{(\mathbf{2 0}),} 12.7 \%$ (at age 7 years) to $18.8 \%$ (at age 12 years) in Indian schoolaged boys $^{(\mathbf{2 1}),} 18.7 \%$ in Chad in $2002^{(\mathbf{2 2}),} 15 \%-40 \%$ in South Africa in $2003^{(\mathbf{2 3}),} 25 \%$ in Morocco in $2004^{(\mathbf{2 4}),} 18.3 \%$ in Kenya in $2005^{(\mathbf{2 5})}$, and $16.5 \%$ in rural areas of southern Pakistan in $2005^{(\mathbf{2 6}) .}$ The prevalence of stunting only, and concurrent stunting and underweight, in Baghdad, Iraq 2009 were $18.7 \%$ and $13.5 \%$ respectively ${ }^{(27)}$ Chronic undernutrition, as evidenced by the proportion of stunted children, was of mild prevalence in this school-aged cohort $(18.7 \%)$ and the overall prevalence of linear growth deficit was 53.3\%. Subtracting the normal baseline or expected

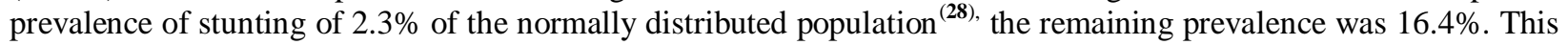
is belowthe prevalence of stunting (22.2\%) reported in the Administrative Committee on Coordination/ SubCommittee on Nutrition (ACC/SCN) $3^{\text {rd }}$. report on the world nutrition situation for the Near East/North Africa region $^{(29)}$. 
Stunting reduces total energy expenditure (resting+active) in children. Rather, children with shorter stature and less lean body mass have lower total energy expenditure. Complex interactions between body size, body composition, and metabolic activity appear to elevate the risk for later life obesity of children ${ }^{(\mathbf{1 8})}$. In own study, there was a gradual increase of BMI, was observed as increase levels of BMI-for-age Z-score for both age groups. Concerns have been raised about childhood obesity and its long-term impact on the health of children (Hodgkin et al., 2010). The problem of childhood obesity is accelerating throughout the world. Obesity is the result of excess body fat ${ }^{(30)}$.

Fisheret al., found that more than three quarters of boys (82\%) and girls (77\%) were of normal weight. Twice as many girls $(6 \%)$ than boys $(3 \%)$ were obese ${ }^{(31)}$. Michelset al., mentioned that the last decades, the prevalence of childhood obesity has increased ${ }^{(32)}$.

The overweight and obesity percentages observed in the baseline children's body composition and stress survey are low compared to the most recent reference data available for Flemish children ${ }^{(33) .}$ Rural children had a significantly lower BMI, smaller waist circumferences and thinner skinfold measurements than urban children. The differences in skin fold thicknesses remained after controlling for ethnicity and socioeconomic status ${ }^{(13) .}$

Usual school-meal participation was significantly related to children's BMI but in opposite directions- positively for breakfast and inversely for lunch ${ }^{(34)}$.Walking or bicycling to school (ie, active commuting) has shown promise for improving physical activity and preventing obesity in youth. Active commuting was inversely associated with BMI $\mathrm{z}$-score $(\beta=-0.07, \mathrm{P}=.046)$ and skinfolds $(\beta=-0.06, \mathrm{P}=.029)$, and positively associated with overall daily $(\beta=0.12$, $\mathrm{P}=.024)$ and before- and after-school $(\beta=0.20, \mathrm{P}<.001)$ moderate-to-vigorous physical activity ${ }^{(35)}$. Another study curried out on healthy children $(n=245)$, aged 4-16 years, were included (124 girls and 121 boys). A gender analysis revealed that Amplitude-Dependent Speed Of Sound (Ad-SoS) and Broadband Ultrasound Attenuation (BUA) parameters increased significantly with age and that both positively correlated with age, weight, height, BMI, Fat percentage, fat mass, lean mass (FFM) and total body water (TBWater). For both genders, (Ad-SoS) showed significant and positive correlations with age, weight, height, BMI, FFM, BUA and TBWate ${ }^{(36) .}$

There are essentially six relevant levels, which could be involved in prevention of child and adolescent obesity: family (child, parents, siblings, etc), schools, health professionals, government, industry and media. Evidence-based health promotion programs has to be given a high priority ${ }^{(30)}$.

\section{Nutrient intake:-}

Our results revealed that,a positive significant relationship was detected between energy intake and each of fat, carbohydrate and total sugars intakes, also there was a positive significant association at level (5\%) between it each of protein and BMI for age Zscor. It could be noticed that calories intake was lower than AI, tending to be lower of boys in age group $>8$ years than boys in age group $\leq 8$ years, these results agreed withChitra, and Reddy ${ }^{(37)}$ who reported that mean nutrient intakes calculated from 24-hour recalls revealed that the children's diets were inadequate compared with the recommended values for energy and protein. In disabled children, while the mean energy intake was more than $90 \%$ of the amount required, Despite absence of significant difference in energy and fat intake, the intakes of protein, calcium and riboflavin were significantly lower in girls than in boys ${ }^{(38)}$.

Our results revealed that, total protein intake was highly increased for boys in age group $\leq 8$ (y-old) of AI compared with boys in age group $>8$ (y-old). Concerning carbohydrate, fiber and total sugars there were insignificant difference between both groups, meanwhile fiber intake for boys in age group $>8$ (y-old) was severe decreased compared with daily requirements.

The carbohydrate and fat contents of the diet as a percent of energy did not differ comparing normal and overweight children, but the percentage of protein was significantly higher in overweight children. Intakes of energy, carbohydrates and fat were not significantly correlated with body mass index (BMI) standard deviation scores (SDS) after controlling for age, gender and total energy for carbohydrates and fat ${ }^{(39)}$. Malnutrition (low weight and stunting) is quite prevalent among Iranian children with motor disabilities and it is more prevalent in girls than in boys. It seems that poor food composition is a more important contributing factor than total low calorie intake ${ }^{(\mathbf{3 8}) \text {. }}$

Our results found that, calories intake was lower than AI, in spite $21 \%$ for total samples were obese, these results may be due to bad lifestyle or disturbance of thyroid gland.In obese children, an increased free triiodothyronine(fT3) concentration is the most frequent thyroid function abnormality. Serum fT3 and TSH correlate with BMI. Moderate 
weight loss frequently restores these abnormalities ${ }^{(40) .}$ It is important to know and to follow nutritional factors, energy intake and composition of the diet, nutrition and hormonal status, food preferences and behavior, and the influence of non-nutritional factors ${ }^{(30)}$.

Aeberliet al. ${ }^{(39)}$ reported that more hours spent on watching TV and playing computer games are associated with overweight in primary school-aged Swiss children. Multi-component model of nutrition and lifestyle education was successful in improving the nutrition-related knowledge, eating habits and lifestyle practices, and resulted in beneficial changes in anthropometric and biochemical profiles ${ }^{(\mathbf{4 1 )}}$. Family dietary coaching improves nutritional intake in free-living children and parents, with beneficial effects on weight control in parents ${ }^{(42)}$. Another study mentioned that, Prepubertal gymnasts have higher percentage of fat free mass and daily energy expenditure and dietary intakes, but lower percent body fat than age matched controls ${ }^{(43) .}$ In the study of 239 primary school children, there were no significant differences in daily activity levels, body composition, or estimated dietary energy intake between those who walk to school (Walk) and those who travel by car (CAR; $\mathrm{p}<.05)$. Walk children were more active between 8 a.m. and 9 a.m. and 3 p.m. and 4 p.m. than CAR children $(p<0.05)$. In addition, there were no significant differences in the main analysis when participants were sub-grouped by gender and age ${ }^{(44) .}$

\section{Conclusion and Recommendation:-}

Differences were found in body composition of boys in age group $\leq 8$ years being leaner than boys in age group $>8$ years. Obesity and stunting are prevalent and undernutrition, especially severe thinness, was uncommon in this target group. The most important factors founded in the current study was poor calories and fiber intake compared with AI.The results arrived at suggest inevitable increase of calories takinginto consideration variety and balance of diets and children must do regular exercise. Moreover nutrition education is recommended as one of the long-term approaches for improving nutrition and health status for boys and their parents. Future more researches are needed to evaluated the prevalence of thyroid function abnormalities with weight loss and obesity for boys.

\section{Limitations:-}

The limitation in this study may be related to the small sample size.

\section{References:-}

1. Leslie, J. and Jamison, D. (1990). Health and nutrition considerations in education planning. Educational consequences of health problems among school-age. children.http://archive.unu.edu/unupress/food/8F123e/8F123E03.htm.

2. 2.Agnes, M. and Guralnik, D.B. (2004). Webster's New World College Dictionary, 4ed, Wiley Publishing. Available on YourDictionary.com, http:// www.your dictionary.com/ preschool.

3. 3.Prema, R. and Hema, G. (2009). Under nutrition\& risk of infection in preschool children an Indian J. Med. Res. 130, PP 579-583.

4. 4.Calliara, M. (1989). Profile of an Indian Child. Social Welfare; 36: 33 - 4.

5. 5.Nemati, A., Barak, M., Naghizadeh-Baghi, A., Abbasgholizadeh, N., Homapou, F., Hazrati, S., Sepehram, V. and Shakiba, B. (2008). Relationships Between Anthropometrical Indices and Socio-Economic Differences for Children at 6 Years Old Living in Urban Areas of Ardebil, Iran

6. 6.Anwer, I. and Awan, J.A. (2003). Nutritional status comparison of rural with urban school children in Faisalabad district, Pakistan.

7. 7.Tara, L., Alexandra, K., Jared, B., Kate, A., SuAnne, M. and Ronald, J. (2010). Dietary Intakes and Physical Activity among Preschool Aged Children living in Rural American Indian Communities Prior to a Family-based Healthy Lifestyle Intervention.110(7):1049-1057.

8. 8.Tomkins, A. (2001). Vitamin and mineral nutrition for the health and development of the children of Europe. Public Health Nutrition 4 No 1A: 91-99.

9. Reilly, J.J. (2002). Assessment of childhood obesity: national reference data or international approach? Obes Res; $10: 838-40$.

10. Fomon, S.J., Haschke, F., Ziegler, E.E. and Nelson, S.E. (1982). Body composition of reference children from birth to age 10 years. Am J Clin Nutr;35:1169-75.

11. C.D.P.H. (2011). Centers for Disease Control and Prevention. Hyattsville, MD: National Center for Health Statistics; [Accessed January 5, 2011]. National Health and Nutrition Examination Survey. Anthropometry Procedures Manual. Available at http://www.cdc.gov/nchs/data/nhanes/nhanes_03_04/BM.pdf. 
12. Michele, G., Sara, L., and Sandra, D. (2004). "Nutrition in Patient Care". In Sandra DeYoung. Foundations and clinical applications of nutrition: a nursing approach ( $3^{\text {rd }}$ Ed.). Elsevier Health Sciences. pp. 406-407.

13. Hodgkin, E., Hamlin, M.J., Ross, J.J. and Peters, F. (2010) Obesity, energy intake and physical activity in rural and urban New Zealand children. Rural Remote Health;10(2):1336.

14. USDA United States Department of Agriculture (2012).National Nutrient Database for Standard Reference. Department of Agriculture, Agricultural Research Service. Release 25. Nutrient Data Laboratory Home Page, http://www.ars.usda.gov/ba/bhnrc/ndl.

15. Institute of Medicine IOM (2005). Dietary Reference Intakes for Energy, Carbohydrate, Fiber, Fat, Fatty Acids, Cholesterol, Protein, and Amino Acids (Macronutrients).Washington, DC: National Academy Press.

16. RDA (1989): Recommended Dietary Allowances, 10th Ed., Food \& Nutrition Board, National Academy of Sciences Press, USA.

17. DRI (2002): Dietary Reference Intake for Energy, Carbohydrate, Fiber, Fat, Fatty acid, Cholesterol,F.N.B., Institue of Medicine, I.O.M. This report may be accessed Via WWW.nap,edu

18. Wilson, H.J., Dickinson, F., Hoffman, D.J., Griffiths, P.L., Bogin, B. and Varela-Silva, M.I. (2012). Fat free mass explains the relationship between stunting and energy expenditure in urban Mexican Maya children. J. Ann Hum Biol. Sep;39(5):432-9.

19. Gross, R., de Lima, FD., de Freitas, CJ and Gross, U. (1990). The relationships between selected anthropometric and socioeconomic data in schoolchildren from different social stratain Rio de Janeiro, Brazil. Review saudepublica, 24(1):11-9.

20. Abidoye, R.O. and Akande, P.A. (2000). Nutritional status of public primary school children: a comparison between an upland and riverine area of Ojo LGA, Lagos State Nigeria. Nutrition and health, 14(4):225-40.

21. De Onis, M., Dasgupta, P., Saha, S., Sengupta, D. and Blossner, M. (2001). National Center for Health Statistics reference and the growth of Indian adolescent boys. American journal of clinical nutrition, 74(2):24853.

22. Beasley, M., Brooker, S., Ndinaromtan, M., Majiouroum, E.M., Baboguel, M. and Djenguinabe, E. (2002). First nationwide survey of the health of schoolchildren in Chad. Tropical medicine and international health, 7(7):625-30.

23. Jinabhai1, C.C., Taylor, M. and Sullivan, K.R.(2003). Implications of the prevalence of stunting, overweight and obesity amongst South African primary school children: a possible nutritional transition? European journal of clinical nutrition,57:358-65.

24. Aboussaleh, Y., Ahami, A. O. T., Azzaoui, F.-Z., El Hioui, M. and Boukhari, A. (2004). A diversified diet may reduce school age children stunting in North Western Morocco. Asia Pacific journal clinical nutrition, 13(Suppl.):S116.

25. Friedman, J.F., Howard, P. A., Minel, L.B., Terlouw, D.J., Okello, N., Vulule, M., Hawley,W.A., Nahlem, B. L. and Kuile, F.T. (2005). Progression of stunting and its predictors among school-aged children in western Kenya. European journal of clinical nutrition, 59(8):914-22.

26. Khuwaja, S., Selwyn, B.J. and Shah, S.M. (2005). Prevalence and correlates of stunting among primary school children in rural areas of southern Pakistan. Journal of tropicalpediatrics, 51(2):72-7.

27. Al-Saffar, A.J. (2009). Stunting among primary-school children: a sample from Baghdad, Iraq. La Revue de Santé de la Méditerranée orientale, Vol. 15, N 2.

28. WHO (2007).Global database on child growth and malnutrition. National Center of Health Statistics/World Health Organization reference data [online database] (http://www.who.int/nutgrowthdb/reference/en/, accessed 9 July 2011).

29. TRWNS, (1997). Third report on the world nutrition situation. Geneva, Administrative Committee on Coordination/Sub-Committee on Nutrition and International Food Policy Research Institute.

30. Flodmark, C.E., Lissau, I., Moreno, L.A., Pietrobelli, A. and Widhalm, K. (2004). New insights into the field of children and adolescents' obesity: the European perspective. Int J. ObesRelatMetab Disord;28(10):1189-96.

31. Fisher, L., Fraser, J. and Alexander, C.(2006). Caregivers' inability to identify childhood adiposity: a crosssectional survey of rural children and their caregivers' attitudes. Aust J. Rural Health. Apr;14(2):56-61.

32. Michels, N., Vanaelst, B., Vyncke, K., Sioen, I., Huybrechts, I., De Vriendt, T. and De Henauw, S. (2012). Children's Body composition and Stress - the ChiBS study: aims, design, methods, population and participation characteristics. J. Arch Public Health. 70(1):17. [Epub ahead of print]

33. Roelants, M., Hauspie, R. and Hoppenbrouwers, K. (2009). References for growth and pubertal development from birth to 21 years in Flanders, Belgium. Ann Hum Biol, 36:680-694.

34. Paxton-Aiken, A.E., Baxter, S.D., Tebbs, J.M., Finney, C.J., Guinn, C.H. and Royer, J.A. (2012). How accurate are parental responses concerning their fourth-grade children's school-meal participation, and what is the 
relationship between children's body mass index and school-meal participation based on parental responses? Int J. BehavNutrPhys Act.19;9:30

35. Mendoza, J.A., Watson, K., Nguyen, N., Cerin, E., Baranowski, T. and Nicklas, T.A. (2011). Active commuting to school and association with physical activity and adiposity among US youth. J. Phys Act Health; 8(4):488495.

36. Lavado-Garcia, J.M., Calderon-Garcia, J.F., Moran, J.M., Canal-Macias, M.L., Rodriguez-Dominguez, T. and Pedrera-Zamorano, J.D. (2012).Bone mass of Spanish school children: impact of anthropometric, dietary and body composition factors. J. Bone Miner Metab; 30(2):193-201.

37. Chitra, U. and Reddy, C.R. (2007). The role of breakfast in nutrient intake of urban schoolchildren. J. of Public Health Nutr.;10(1):55-8.

38. Neyestani, T.R., Dadkhah-Piraghaj, M., Haydari, H., Zowghi, T., Nikooyeh, B., Houshyar-Rad, A., Nematy, M. and Maddah, M. (2010). Nutritional status of the Iranian children with physical disability: a cross-sectional study. Asia Pac J. Clin. Nutr;19(2):223-230.

39. Aeberli, I., Kaspar, M. and Zimmermann, M.B. (2007). Dietary intake and physical activity of normal weight and overweight 6 to 14 year old Swiss children. Swiss Med Wkly. Jul 28;137(29-30):424-30.

40. Marras, V., Casini, M.R., Pilia, S., Carta, D., Civolani, P., Porcu, M., Uccheddu, A.P. and Loche, S. (2010). Thyroid function in obese children and adolescents. Horm. Res. Paediatr;73(3):193-7. doi: 10.1159/000284361. Epub 2010 Mar 3.

41. Singhal, N., Misra, A., Shah, P. and Gulati, S. (2010). Effects of controlled school-based multi-component model of nutrition and lifestyle interventions on behavior modification, anthropometry and metabolic risk profile of urban Asian Indian adolescents in North India. Eur J. Clin. Nutr.;64(4):364-73.

42. Paineau, D.L., Beaufils, F., Boulier, A., Cassuto, D.A., Chwalow, J., Combris, P., Couet, C., Jouret, B., Lafay, L., Laville, M., Mahe, S., Ricour, C., Romon, M., Simon, C., Tauber, M., Valensi, P., Chapalain, V., Zourabichvili, O. and Bornet, F. (2008). Family dietary coaching to improve nutritional intakes and body weight control: a randomized controlled trial. Arch PediatrAdolesc Med.;162(1):34-43.

43. Filaire, E. and Lac, G. (2002). Nutritional status and body composition of juvenile elite female gymnasts. J. of Sports Med Phys Fitness;42(1):65-70.

44. Ford, P., Bailey, R., Coleman, D., Woolf-May, K. and Swaine, I. (2007). Activity levels, dietary energy intake, and body composition in children who walk to school. PediatrExerc Sci.;19(4):393-407. 